\title{
O Regimento Inquisitorial de 1774: modernização e dirigismo cultural nos tribunais de fé no reformismo pombalino
}

\author{
Igor Tadeu Camilo Rocha ${ }^{1}$
}

\begin{abstract}
RESUMO
O objetivo deste artigo é analisar o Regimento da Inquisição de Portugal de 1774 e sua articulação com um dirigismo cultural marcante no reformismo pombalino a partir da segunda metade do século XVIII. Tratam-se de políticas tocantes às instituições públicas, sociais, culturais e religiosas de Portugal e colônias, que partiam de uma premissa de que o atraso atribuído a Portugal em relação às nações do norte da Europa seria superado com reformas feitas verticalmente. Para tanto, seria necessária a permanência de instituições como os órgãos de censura e a Inquisição, desde que reformadas e modernizadas, readequadas a "iluminar" as mentalidades, guiando-as rumo à uma razão iluminista delimitada pelo ideário cristão católico. O Regimento da Inquisição de 1774 ao mesmo tempo em que modernizava as formas de punir com a supressão da tortura, das penas públicas como os autos de fé e publicação de listas de penitenciados, terminou com o segredo processual e ainda modificou categorias penais, como, por exemplo, retirando "possessão demoníaca" como evidência válida para delitos como os de feitiçaria. Ele se norteava por um ideal de pureza de fé, de um lado, e secularizador, de outro, contrário tanto à irreligião quanto às formas consideradas supersticiosas e fanáticas de religião. Será discutida a ambiguidade de um regimento inquisitorial que dialogou com os diversos debates iluministas a respeito da aplicação e tipificação de delitos e penas, a despeito do fato de a crítica à repressão das diferenças de religião ser uma tópica fundamental das Luzes.
\end{abstract}

PALAVRAS-CHAVE: Inquisição portuguesa. Regimento de 1774. Ilustração.

\begin{abstract}
This paper analyzes the 1774 Portugal Inquisition's Regiment and its link with the cultural interventionism that marked the Pombalist reformism, which started at the second half of 18th century. These are all the policies that influenced the public, social, cultural and religious institutions of Portugal and its colonies, based in a premise that the backwardness, attributed to Portugal in comparison with European northern countries, would be surpassed by reforms done vertically. Thereunto, it would be necessary the sustenance of some kind of institutions like the censorship and the Inquisition, as long as it was reformed and modernized, readapted to "enlighten" the mentalities, leading them to an enlightened
\end{abstract}

\footnotetext{
${ }^{1}$ Igor Tadeu Camilo Rocha. Mestre em História Social da cultura pela Universidade Federal de Minas Gerais.igortcr@gmail.com
} 
order delimited by Catholic Christian ideals. The Regiment of de 1774, at the same time that it modernized the ways of punishment with the suppression of torture and the public penalties, like the autos-de-fé and the publication of the penitenciado's lists, has finished with the processual secret and, moreover, modified criminal categories, for example, suppressing "demonic possession" as a valid evidence for delicts like witchcraft. It was guided by an ideal of purity of faith, on the one hand, and, on another by a secularizing model, both contrary to irreligion and religious forms that were considered superstitious and fanatical. It will discuss the ambiguity of an inquisitorial regiment that has a dialogue, at some points, with further enlightened debates about the application and characterization of crimes and penalties, despite the enormous criticisms of the repression of religious differences being a fundamental topic of the Enlightenment.

KEYWORDS: Portuguese Inquisition. Inquisition's Regiment of 1774. Enlightenment.

O objetivo deste trabalho é articular dois temas, aparentemente conflitantes, comumente abordados pela historiografia sobre Portugal e o mundo luso-brasileiro na segunda metade do século XVIII. O "ímpeto secularizador" (FALCON, 1993) e modernizante das reformas pombalinas ocorridas a partir de 1750, no reinado de D. José I, com o ministro plenipotenciário Sebastião José de Carvalho e Melo, o Marquês de Pombal, voltado às instituições públicas, sociais, culturais e religiosas de Portugal e colônias; e o dirigismo cultural que partia da premissa de que o atraso português em relação às nações do norte da Europa seria superado com reformas feitas de cima para baixo. Para tanto seria necessária a permanência de instituições como os órgãos de censura e a Inquisição.

Um exemplo desse direcionamento político foi o Regimento da Inquisição de 1774 que ao mesmo tempo em que modernizava as formas de punir e as suas categorias penais, se aproximando de debates iluministas, era norteado por um ideal de pureza de fé ancorado em um projeto de sociedade contrário tanto à irreligião e à libertinagem, ${ }^{2}$ quanto às formas

\footnotetext{
2 A respeito do significado do termo "libertino", é importante aqui pontuar sobre seu significado na Idade Moderna. Ao final do século XVIII, o termo "libertino", utilizado na linguagem comum e em disputas teológicas, antes e depois do século XVIII, possuía pelo menos três acepções, não excludentes entre si, seja na realidade, seja na visão dos críticos do libertinismo. O primeiro, no sentido de depravado em matéria moral, sobretudo sexual; o segundo de diletante mundano e incrédulo; e, por fim, de filósofo cético. Muitas vezes, esses três significados encontravam-se interligados, estando a
} 
supersticiosas, desreguladas e "fanáticas" de religião. Aqui interessa problematizar brevemente esta ambiguidade destacando em um primeiro momento, a articulação que o referido regimento reformado teve com os debates da cultura letrada ilustrada portuguesa, passando por uma discussão a respeito das reformas e, por fim, analisar aspectos internos do próprio Regimento, conforme articulações com a cultura das Luzes.

\section{Luzes portuguesas e a Inquisição}

Com algumas exceções, como no caso de Francisco Xavier de Oliveira, mais conhecido como Cavaleiro de Oliveira, condenado em 1761 por apostasia e por ter sido um ferrenho crítico dos tribunais de fé, ${ }^{3}$ havia um tópico importante na elite intelectual portuguesa à época do Marquês de Pombal em torno dos tribunais do Santo Ofício. Tratava-se da ideia de que a Inquisição não era mais tolerável diante do imperativo de modernizar o país em todos os âmbitos. Não se devia simplesmente suprimi-la, conforme o mesmo tópico que predominava na cultura letrada luso-brasileira, mas adaptá-la a este mesmo projeto modernizador. O pressuposto implícito era o de que ainda que a liberdade de consciência e de religião fosse desejável e salutar para o progresso de Portugal e das colônias, o vulgo não estava

\footnotetext{
licenciosidade sexual associada à incredulidade e ao ceticismo. Os acusados de "libertinagem" foram constantemente alvos de perseguição inquisitorial, o que indica, segundo trabalhos recentes sobre o tema, que houve espaço, ainda que restrito, para a defesa de ideias mais radicais da Ilustração europeia no contexto luso-brasileiro. C.f. VILLALTA, Luiz Carlos. Libertinagens e livros libertinos no mundo luso--brasileiro (1740-1802). In: MEGIANI, Ana Paula Torres; ALGRANTI, Leila Mezan (Org.). O império por escrito: formas de transmissão da cultura letrada no mundo ibérico (séculos XVIXVIII). São Paulo: Alameda/Fapesp/Cátedra Jaime Cortesão, 2009. P. 511-550; CAMILO ROCHA, Igor Tadeu. . "Libertinos, Tolerância religiosa e Inquisição sob o Reformismo ilustrado luso-brasileiro: formulações, difusão e representações (1756- 1807)". [Dissertação de mestrado]. Belo Horizonte: Faculdade de Filosofia e Ciências Humanas da UFMG-FaFICH, 2015.

${ }^{3}$ Francisco Xavier de Oliveira, ou o Cavaleiro de Oliveira, que em sua obra, maior parte publicada em francês, condenava fortemente a Inquisição, instituição que considerava retrógrada e absurda do ponto de vista teológico e político. Converteu-se ao anglicanismo em Londres, e por apostasia foi condenado pela Inquisição, razão pela qual foi queimado em efígie, em 1761. Sua resposta à sentença foi a publicação de livro, Chevalier d'Oliveira brûlé en effigie comme héretique. Comment et porquoi (1762), em que ele evoca a tolerância religiosa, sobretudo dos judeus, e defende, em tom provocativo, que o palácio dos Estaus se torne uma sinagoga. Condena igualmente o Santo Ofício por instituição contrária às leis divinas e humanas. C.f. SCHWARTZ, Stuart. Cada um na sua lei: tolerância religiosa e salvação no mundo atlântico ibérico. São Paulo/Bauru: Companhia das Letras/Edusc, 2009, p. 332 .
} 
preparado para ela. Argumento, inclusive, evocado mesmo pelo próprio Marquês de Pombal à época de sua queda (SANTOS, 2011, p. 85).

Vemos esta tópica no libelo $A$ origem da denominação entre christãosvelhos e christãos-novos em Portugal, de Antônio Nunes Ribeiro Sanches. Nele, o médico e cristão-novo, perseguido pela Inquisição, não propõe a supressão dos tribunais, mas modificações drásticas de seus estilos, sobretudo, no que tange ao segredo processual. Este era acusado de favorecer a punição dos verdadeiros cristãos, induzindo-os a confessar práticas heterodoxas à Inquisição, mesmo quando inocentes. Já as pessoas ímpias, com maior contato com os estilos inquisitoriais, por já terem sido presas ou por terem parentes ou amigos próximos que caíram nas malhas do Santo Ofício, conseguiam administrar os procedimentos de confissão e denúncia com maior eficácia para satisfazer as autoridades e, assim, escapavam. Além do fim da "sediciosa distinção" entre os súditos católicos do monarca, o pensador português propunha que fosse permitido que se fizesse em mesa somente confissões e declarações de culpas, impedindo-se de denunciar mesmo os cúmplices.

Já o ilustrado oratoriano Luiz Antônio Verney faz críticas um tanto semelhantes em carta de 1765, a um interlocutor desconhecido. O "Barbadinho" defende alguns pontos que se aproximam muito das mudanças que vieram à luz com o Regimento de 1774. A Inquisição que para Verney seria "um obstáculo terrível ao bom gosto das ciências e ao progresso e a introdução de muitas outras coisas necessárias e uteis", precisava ser urgentemente reformada, pois "com os presentes regulamentos, se não se tomam as medidas justas para desenraizar as desordens", que, "após a morte do ministro [marquês de Pombal] e do rei [D. José I], elas desenvolver-se-ão imediatamente" (Idem, 2008, p.102).

As mudanças que Verney propõe para a Inquisição, dez medidas ao todo, contém pontos como a supressão da diferença de cristãos-velhos e cristãos-novos, o fim do segredo processual e da consideração da possessão demoníaca como evidência válida para delitos de feitiçaria, bem como várias 
medidas que rechaçam as punições públicas - numa condenação direta aos autos-de-fé e às publicação de listas de penitenciados -, como também o fim da tortura e das penas violentas, e a ampliação dos direitos de defesa dos acusados de qualquer delito (Ibidem, pp. 106-109).

Já na carta do então Conde de Oeiras, Sebastião José de Carvalho e Melo, ao arcebispo de Braga, D. Gaspar de Bragança, datada de 1768, é notável uma preocupação do ministro com a propagação uma religiosidade desajustada um ideal regulado e moderado de catolicismo, que deveria ser desenraizado das mentalidades luso-brasileiras. Nela, o então ministro adverte ao religioso que, sob seu arcebispado, há

(...) a perniciosa leitura de certos livros espirituais, introduzida na cabeça das beatas por alguns frades ignorantes, [e com isso se] tem chegado a produzir grande número de fanáticos de um e outro sexo (MELO, 1822, p. 95).

Lembra que o bispo é vigilante na tarefa de extirpar frades que atuam como "pais espirituais de beatas, que ajuntam congregações delas debaixo de sua direção", e que em cada uma "estabelecem um seminário de fanatismos e entusiasmos devotos", fomentados pela leitura "do pernicioso livro de Alonso Rodrigues, das obras de soror Maria de Lantígua, das fábulas espirituais da madre Agreda e da vida de soror Maria Serio", dentre outros livros semelhantes. Juntamente, adverte ao arcebispo sobre padres que incentivam pessoas a expelirem demônios, "levando após de si os outros grandes séquitos de endemoninhados, que nesta corte e província se extinguiram" após essa prática ter sido proibida e combatida, "de sorte que todos os antecedentes demônios têm fugido para longe do cheiro da estopa da enxárcia velha, que ali se desfia, e do castigo que recebem os que não dão conta das tarefas que lhe são arbitradas (Ibidem, p. 96)."

Noutra carta sobre reformas propostas para a Inquisição Verney faz observação semelhante ao defender a supressão de tipologias de crime de alçada inquisitorial que consideram o pacto com o demônio como evidência válida, pois, de acordo com oratoriano, "aquilo de pacto com o diabo, já se 
sabe que só se pode acreditar em quatro padres e frades ignorantes", já que, com ironia, diz em conclusão que como "observou-se que os diabos têm grande medo de países em que se sabe bem a filosofia, medicina, lei e teologia, porque nunca se arriscam em tais lugares em fazer pacto com nenhum homem (VERNEY, 2008, p. 106)."

$\mathrm{O}$ que se depreende dessa linha de pensamento é a existência de um forte dirigismo, marcante na política cultural pombalina, no contexto do Reformismo ilustrado. Na análise de Cabral de Moncada das mencionadas cartas de Verney, os ataques do oratoriano aos tribunais de fé são vistos como uma maneira de conquistar um "despotismo intolerante", com o qual "far-se-ia da intolerância instrumento e meio para reabilitar uma ideia de tolerância" (MONCADA, 1950, p. 74). Segundo Moncada, Verney acreditava que para se "realizar [a tolerância], era indispensável ilustrar, iluminar o espírito dos povos e governos", por este motivo, não propunha a supressão da Inquisição ou a simples retirada da censura das mãos de eclesiásticos. Entendia que os preconceitos da nação causados e reproduzidos por séculos de educação jesuítica e excessivos privilégios clericais, aliados à baixa difusão da filosofia e ciência modernas, exigiam uma intervenção mais direta de uma elite ilustrada, ligada à Coroa (Ibidem, pp. 93-95).

A leitura das fontes e dos debates historiográficos recentes, entretanto, não confirmam a tese de Moncada de que houve uso da intolerância para se alcançar a tolerância, embora a sua ideia da religião instrumentum regni indique um aspecto importante do pombalismo. Tratase do dirigismo cultural, marcante na política do ministro de D. Jose I e com alguma continuidade ao longo do Reformismo Ilustrado. Esse dirigismo engloba, pelo menos, duas frentes de ação da política pombalina, tocantes aos campos da religião e a cultura, dentre outros.

A primeira, em concordância com as análises de Ivan Teixeira (TEIXEIRA, 1999, pp. 67-130) e Ana Cristina Araújo (ARAÚJO, 2014, pp. 16-48), trata da política de envolvimento de muitos letrados no projeto político do Marquês de Pombal, por meio de mecenato e do encômio, bem 
como da inserção deles em redes clientelares de homens de letras mais ou menos coevos às delimitações do discurso oficial. Tanto se desenvolve uma literatura elogiosa às ações do reinado josefino, difundindo valores hegemonizados naquele período, como se desenvolvem contornos específicos alinhados com o Iluminismo católico que delimitam diversos aspectos estéticos e temáticos das obras poéticas, literárias, historiográficas, tratadísticas (HANSEN, 1997, pp. 40-53).

A segunda frente, aqui em concordância com Moncada, se pauta na ideia de que o atraso português seria vencido com um conjunto de ações vindas "de cima", com um poder exercido por homens ilustrados e ajustados com um ideário iluminista católico, contraposto tanto às forças que simbolizavam o "antigo", i.e., setores do clero, sobretudo os jesuítas, mas também outras vertentes do mesmo e da nobreza, bem como as variantes mais radicais do Iluminismo. 4

Junto com as linhas gerais do Iluminismo católico os "prejuízos"5 nacionais seriam combatidos alinhando-se a verdade católica com o ideário dos "modernos" contrários à Escolástica, ao excesso de privilégios do clero e da ingerência da Santa Sé romana em assuntos religiosos "nacionais". O combate se daria ainda a partir da apropriação de uma epistemologia tributária do experimentalismo inglês, de um lado, mas de outro refratando defesas da liberdade de consciência, relativismos de base ético-teológica ou princípios irreligiosos irradiados de diversos pontos da Europa desde meados do século XVII, marcantes nas Luzes. ${ }^{6}$

\footnotetext{
${ }^{4}$ É uma ideia bem visível na carta de Verney sobre a perseguição aos jesuítas. O barbadinho defendia que bons princípios, uteis para a liberdade e para o progresso das ciências e letras em Portugal, reforma completa das mentalidades e extirpação dos preconceitos nacionais teriam lugar apenas com uma boa educação do príncipe, segundo o ideário moderno, e também de cerca-lo de uma elite ilustrada, afastando do monarca os aduladores -os jesuítas, e seu espírito de sedição, obscurantismo e despotismo. C.f VERNEY, Luís Antônio. Cartas Italianas. CURADO, Ana Lúcia; CURADO, Manuel (orgs.). Lisboa: Edições Sílabo, 2008. p. 83-84.

5 Em um sentido similar ao que chamamos de "preconceito".

6 Uma atualização desse debate sobre o perfil hegemônico das Luzes ibéricas pode ser vista em trabalho do historiador estadunidense Jonathan Israel, embora seja necessária a ressalva de que é uma análise válida apenas para uma cultura letrada, no sentido estrito do termo. De acordo com a minha avaliação, devo acrescentar, há uma série de outras vertentes das Luzes no mundo lusobrasileiro que se desenvolveram à parte do discurso oficial, que engloba desde os chamados "libertinos", passando pelas lojas e sociabilidades maçônicas, estudantes coimbrãos e "estrangeirados",
} 


\section{Reformismo ilustrado e a Inquisição portuguesa}

A Inquisição de Portugal, após a morte de D. Nuno da Cunha Ataíde e Melo, em 1750, juntamente com a ascensão do Marquês de Pombal como ministro de D. José I, passou por fortes mudanças. Segundo Giuseppe Marcocci e José Pedro Paiva, essas mudanças afirmaram o incisivo controle do Santo Ofício por parte da Coroa de Portugal, alcançando durante o período pombalino uma certa conformidade com o que fora idealizado por D. João III antes da implantação dos tribunais e jamais alcançado plenamente, em especial após a ascensão do cardeal D. Henrique ao posto de inquisidorgeral no final do século XVI. Desde então, a Inquisição portuguesa gozou de grande poder e de relativa independência em relação ao soberano (MARCOCCI; PAIVA, 2013, pp. 333-334).

$\mathrm{O}$ argumento destes historiadores se aproxima muito dos utilizados na Introdução do Regimento de 1774, escrita pelo cardeal D. Cosme da Cunha, na qual se afirmava que, com as reformas empreendidas pelo referido regimento, o Santo Ofício reencontraria os ideais de sua préfundação que foram corrompidos. A diferença, no entanto, está no tom acusatório que o religioso emprega contra os jesuítas pela dita corrupção.

Nessa Introdução o Cardeal refere-se ao período compreendido entre todas as regências da Inquisição portuguesa após a morte de D. Sebastião (1578) e a confirmação do referido Regimento, no século XVIII, como um "funesto período dos dois ultimo [sic] séculos em que as ordenações destes Reinos, os estatutos da Universidade de Coimbra, e a moral Cristã, haviam

\footnotetext{
dentre outros. Essa discussão também pode ser vista em autores que tratam temas específicos do Iluminismo católico, como é o caso de Juan Pablo Dominguez. O autor explora as disputas e elaborações práticas, políticas, teóricas e teológicas a respeito do conceito de "tolerância" nos países católicos, no sul da Europa, no setecentos. Ainda que sem citar Israel, chega a algumas conclusões que guardam alguma semelhança nesse ponto, como o fato de haver uma Ilustração, no setecentos, definida dentro de contornos católicos de um establishment ibérico, mais ou menos alinhados com tendências originadas noutros países, como o jansenismo, regalismo, febronismo, dentre outras. C.f. ISRAEL, Jonathan I. Iluminismo Radical: a filosofia e a construção da modernidade (1650-1750). Tradução: Claudio Blanc. São Paulo: Editora Masdras, 2009, pp. 577-590; DOMÍNGUEZ, Juan Pablo. Reformismo cristiano y tolerancia en España a finales del siglo XVIII. Hispania Sacra, v. LXV, n. Extra II, p. 113-172, 2013. p. 116-117 e 120-121.
} 
padecido tantas e tão perniciosas alterações", por efeito dos "mesmos estratagemas da terribilidade jesuítica”, que perverteram leis fundamentais da fundação dos tribunais, especialmente seu caráter régio. Ainda de acordo com o Cardeal, a Inquisição tornou-se, sob a tutela dos jesuítas, uma "congregação de eclesiásticos independentes, e despóticos, em um corpo acéfalo e absoluto no meio de uma Monarquia", e também "um monstro tal e tão espantoso que causou tanto medo a Portugal e seus domínios e tanto horror à Europa inteira, como tem sido notório em todo o universo (SIQUEIRA, 1996, pp. 969-970).”

Ainda na Introdução do Regimento de 1774, que, segundo Luiz Antônio de Oliveira Ramos (RAMOS,1988, pp. 41-64), foi o ápice das reformas pombalinas dos tribunais do Santo Ofício de Portugal, vemos outras duras críticas do Cardeal da Cunha aos jesuítas que sinalizam pontos importantes das políticas pombalinas sobre a Inquisição. Primeiramente, destacamos que o Cardeal acusou os jesuítas de, "com sua malícia, cometer um crime contra a religião cristã por subverter", nos regimentos anteriores ao de 1774 (sobretudo os de 1613 e de 1640, segundo ele mais afetados pelos "estratagemas" dos inacianos, embora critique em alguns pontos o anterior, de 1546), "todos os direitos Natural, Divino, e Positivo: todos os Princípios Morais, e toda a Caridade Cristã; e até os ditames da mesma humanidade", ao estabelecer "Estilos" do Santo Ofício, que na verdade eram nada mais que toda sorte de abusos encobertos com "o impenetrável véu de um supersticioso mistério, o qual persuadia que ninguém se podia atrever a perscrutar, sem cometer um crime contra a Religião (SIQUEIRA, 1996. pp. 970-971)."

De fato os Estilos do Santo Ofício português foram fortemente alterados no reformismo pombalino, mas antes de tratar desse assunto alguns outros pontos merecem destaque. Um dos primeiros e decisivos passos de Pombal para afirmar seu poder sobre o Santo Ofício foi colocar pessoas de sua confiança ou diretamente subordinadas a ele em posiçõeschave na hierarquia inquisitorial (MARCOCCI; PAIVA, 2013, p. 334). Por 
exemplo, ao influenciar na escolha de D. José de Bragança, em 24 de setembro de 1756, à posição de inquisidor-geral, sem que este tivesse qualquer experiência ou histórico na Inquisição, ao qual se seguiram, segundo Ramos, "várias individualidades submissas à orientação de Sebastião de Carvalho e Melo", como D. Paulo de Carvalho e Melo, irmão do Marquês de Pombal, o próprio Cardeal Cosme da Cunha, além de D. José de Bragança (RAMOS, 1988, p. 43).

De acordo com Marcocci e Paiva, o objetivo do Marquês de Pombal era reabilitar o Santo Ofício do declínio, acentuado após o terremoto de $1755,{ }^{7}$ mas que acompanhava um contexto maior de crises econômicas e políticas de Portugal ao final do reinado de $\mathrm{D}$. João $\mathrm{V}$, e para tanto o submeteria mais fortemente ao Estado de maneira que ambos lucravam. O Santo Ofício se reabilitaria e o Estado o dominaria, de forma a poder contar com seu aparato para confrontar possíveis oposições. Dessa maneira, dentre as

\footnotetext{
7 O sismo de 1755, que trouxe consequências dramáticas a todo Portugal e não deixou por menos instituições como a Inquisição portuguesa. Para Giuseppe Marcocci e José Pedro Paiva, ele significou um momento especialmente marcante dentro de um contexto mais amplo de decadência dos tribunais de fé, anteriores ao seu controle mais incisivo por parte do Marquês de Pombal. Isso se deu porque, a partir de 1750, após a morte do inquisidor geral D. Nuno da Cunha e Ataíde e Melo, bastante próxima ao falecimento de D. João $\mathrm{V}$, o cargo de inquisidor geral passou por um período de vacância de oito anos. O Conselho Geral, que assumira a governação dos tribunais, designando para isso uma equipe formada pelo frei Rodrigo de Lancastre, Nuno da Silva Teles, Antônio Ribeiro de Abreu, João Pais do Amaral, além de Manuel de Almeida Carneiro e Francisco Mendo Trigoso, estes últimos sendo os únicos de serviços mais recentes à Inquisição, entrados respectivamente em 1741 e 1745 - os demais, eram ligados ao Santo Ofício desde datas que vão de 1714 até 1734 . Nesse período, confirmou-se a tendência de decréscimo de condenações e processos concluídos, assim como publicações de sentenças e autos-de-fé, em grande medida decorrentes de uma significativa crise econômica que se abateu sobre a instituição. No terremoto de 1 de novembro de 1755, em meio a este quadro de crises, várias instalações da Inquisição de Lisboa foram abaladas de forma considerável, como as do palácio do Rossio, assim como o destinado à habitação do inquisidor-geral, que foi completamente arruinado. Houve grande repercussão, à época, das tentativas de fugas de presos, aproveitando-se da situação caótica e também foi quando o mesmo Tribunal de Lisboa se viu obrigado a funcionar em barracas instaladas no Rossio, enquanto se tentavam reconstruir às pressas suas instalações, situação que durou até 1756. Não menos importante é o fato de se tratar de um ponto pacífico da historiografia que o poderio alcançado por Sebastião José de Carvalho e Mello, em grande medida, se deve à sua atuação quando da ocorrência do referido terremoto, como afirma Kenneth Maxwell, por exemplo. Dessa maneira, diante de um tribunal em crise desde os derradeiros anos da "Inquisição Barroca" - período que, segundo Marcocci e Paiva corresponde à restauração dos tribunais de fé portugueses, em 1681, até a morte de D. Nuno da Cunha e Ataíde e Melo, marcado pelo apogeu dos tribunais em termos enraizamento institucional e social, além da magnificência e fausto em suas cerimônias públicas-, abriu-se também ao ministro de D. José I uma espécie de "janela de oportunidades" em que se viabilizou sua instrumentalização e controle da Inquisição portuguesa, no contexto do Reformismo Ilustrado. C.f. MARCOCCI, Giuseppe \& PAIVA, José Pedro. História da Inquisição portuguesa. Op. Cit. pp. 302-302; MAXWELL, Keneth. Marquês de Pombal: paradoxo do Iluminismo. Trad. Antônio de Pádua Danesi. Rio de Janeiro: Paz e Terra, 1996. pp. 26-32.
} 
primeiras medidas tomadas nesse sentido, destaca-se o alvará de 20 de maio de 1769, que equiparou o Santo Ofício a qualquer outro tribunal régio. Além disso, foi retirado qualquer poder de polícia da Inquisição, função dada à Intendência-Geral de Polícia, em 1768 (MAXWELL,1996, p. 99). Nesse alvará ainda se acrescenta que o despacho inquisitorial deveria ser dado em nome do rei, como que a sua jurisdição emanasse do soberano, e não da delegação papal que o inquisidor-geral recebia. Ao alvará de maio de 1769, seguiu-se o alvará de 12 de dezembro do mesmo ano, proibindo a venda e a circulação de livros de autores que denegrissem a imagem do Santo Ofício (MARCOCCI; PAIVA, pp. 349-350).

Além disso, buscou-se reestabelecer as relações diplomáticas com a Santa Sé de Roma, mas vincando-se bem as posições de Portugal e da Santa Sé, isto é, reafirmando-se a soberania da Coroa. Indicativo disso foi o pedido feito ao papa para modificar a redação da bula que promovia o inquisidorgeral ao cargo, deixando clara a submissão deste à Coroa. O escolhido nesse processo foi justamente, o cardeal D. João Cosme da Cunha (Ibidem, pp. 351-353). Com a criação da Real Mesa Censória, em 1768, substituindo-se a censura trina realizada pelo Santo Ofício pelo Desembargo do Paço e pelos tribunais eclesiásticos existentes em cada um dos bispados, a Inquisição praticamente perdeu o papel na censura de livros, se limitando à perseguição de alguns dos leitores de obras defesas que incorressem em delito de heresia (VILLALTA, 2015, pp. 180-182; NOVINSKY, 1990, pp. 357 371).

Mas a mudança que incidiu de maneira mais aguda no Santo Ofício foi a lei de maio 1773 que acabava com a distinção entre cristãos-velhos e cristãos-novos, complementada por outra de 15 de dezembro do mesmo ano, que abolia a infâmia dos réus condenados pela Inquisição que impedia que eles e seus descendentes ficassem inábeis a receber ofícios e dignidades da Coroa. Há de se acrescentar que os processos contra cristãos-novos e 
judaizantes encerraram-se antes de $1773 .{ }^{8}$ Outra característica marcante é o claro direcionamento das ações dos tribunais de fé contra inimigos políticos do Marquês de Pombal. O atentado ao soberano D. José I em 3 de setembro de 1758 acirrou uma forte perseguição aos jesuítas. Isso porque a Junta de Inconfidência, com juízes indicados pelo ministro de D. José concluiu, após diversos interrogatórios, que jesuítas foram instigadores morais do atentado. Além disso, foram presos alguns adversários políticos de Carvalho e Melo, como o Marquês de Távora (FALCON,1993, pp. 377-378).

Neste contexto de grandes mudanças estruturais na Inquisição de Portugal, sintetizadas no Regimento de 1774, mas em consonância com pontos defendidos por diversos pensadores mais ou menos coevos ao reformismo pombalino, cumpre agora analisar as mudanças nos estilos, i.e., procedimentos processuais e mesmo a lógica de punição inquisitorial que passou por fortes mudanças, algumas sob influência do Iluminismo.

\section{O Regimento de 1774}

Em matéria de aspectos punitivos, vemos no Regimento de 1774 pontos que remetem a um notável processo de secularização que teve lugar no contexto português na segunda metade do setecentos. Contexto este marcado por episódios dramáticos como o julgamento e execução do jesuíta Gabriel Malagrida, em 1761, e a expulsão da mesma Companhia de Jesus,

\footnotetext{
${ }^{8}$ De acordo com Antônio José Saraiva as reformas pombalinas no Santo Ofício assentaram-se em dois eixos: o primeiro, já referido, de que os tribunais inquisitoriais seriam régios, e não eclesiásticos, e um segundo, que se ajustava com opiniões de ilustrados, tais como Ribeiro Sanches, Verney e D. Luís da Cunha, de que as leis inquisitoriais, especialmente a distinção entre cristãos-velhos e cristãos-novos, eram a "causa de haver tantos judeus em Portugal", não sua consequência. Isso, segundo o autor, levou Pombal a tomar medidas concretas para eliminar essa distinção, além de suprimir a perseguição aos judeus e cristãos-novos. Dentre as medidas que Saraiva destaca para esse fim, estão o alvará de maio de 1768, em que se manda destruir e anular as listas de cristãos-novos que teriam contribuído para pagar o preço da compra dos perdões gerais ou outros benefícios diretamente da Coroa, e aquelas que visavam acabar com o grupo dos "puritanos". Na prática, acompanhando essas medidas, entre 1764 e 1768, cessaram completamente, nos tribunais de Lisboa, Coimbra e Évora, as perseguições contra judeus e cristãos-novos. Cf. SARAIVA, Antônio José. Inquisição e cristãos novos. Lisboa: Editorial Estampa, 1994. $6^{a}$ edição. pp.204-205; MARCOCCI, Giuseppe e PAIVA, José Pedro. História da Inquisição portuguesa. Op. Cit. p. 359.
} 
em 1759, além das reformas que atingiram a Universidade de Coimbra e toda a relação entre Estado e clerezia.

Trata-se de um processo de secularização no qual se deve entender que o campo religioso, i. e. tomando, aqui, a categoria desenvolvida por Pierre Bourdieu ${ }^{9}$, estava sendo disputado pela Coroa. O projeto políticoreligioso de matriz regalista, conjugado a um ideal de pureza de fé fincado no ideal "regulado" segundo o racionalismo iluminista, se articulava com a busca do poder estatal por delimitar seus espaços de controle das influências externas, como o da Santa Sé romana, e também pela disputa de controle do religioso com setores dos cleros regular e secular (STEFANO, 2008, pp. 157178). Uma Inquisição "secularizada" se inseria nesse horizonte reformista e isso se tornava visível em alguns aspectos tocantes às reformas nas tipologias de crime e delito, nas maneiras de punir e, ainda, nos diálogos com os debates do Iluminismo a respeito desses temas.

\footnotetext{
${ }^{9}$ Segundo Bourdieu, o campo religioso remete a uma divisão social do trabalho, em que se destaca da sociedade um grupo de indivíduos, portadores de determinado capital cultural e simbólico, que se apresentam como detentores e controladores de uma verdade religiosa, e que se organizam de forma a administrar o que chama de "bens religiosos" e "bens de salvação", dentro dos quais se incluem ritos diversos, práticas religiosas, interpretação autorizada e legítima das escrituras, dentre outros bens, observando-se uma moralização paulatina dessas práticas a partir da constituição desse grupo, que forma uma espécie de "corpo sacerdotal". A ideia do autor, com a categoria de campo religioso, é pensar a religião como linguagem, comunicação e meio de estruturação de um sistema que engloba um universo específico de princípios éticos e morais, ideias e organizações sociais (descritas na metáfora do "círculo mágico") que envolvem indivíduos e grupos em determinados contextos. O autor chega a tal categoria articulando posições clássicas sobre a religião de autores como Marx, Webber e Durkheim, de forma que tais construções de fatos e linguagens religiosos não caiam em simplismos, como o automatismo de "cair de círculo em círculo" ou sejam simplesmente isolados das demais estruturas sociais, como a política ou a econômica. Por sua vez, a gênese do campo religioso, segundo Bourdieu, não se reduz a meros desenvolvimentos das transformações sociais e econômicas, sendo o campo religioso estruturado de maneira relativamente autônoma, e constituído de um conjunto de três fatores: primeiramente, a constituição de um corpo sacerdotal, que é parte de uma elite de uma sociedade que experimenta uma divisão de trabalho intelectual e material, juntamente com a própria consolidação do campo sacerdotal no papel de distribuir, gerir e reproduzir bens religiosos; em segundo lugar, a atuação de um corpo leigo na difusão e sedimentação ética dos valores religiosos, ajudando a se consolidar a hierarquia social interna ao campo religioso no que toca o acesso a verdades e mistérios e administração dos bens religiosos; e em terceiro lugar, pensando nesses dois movimentos combinados em um determinado contexto, se desenvolve uma dinâmica em que se consolida um corpo que que monopoliza o capital religioso, juntamente com uma fundamentação ética desse monopólio aceita amplamente, constituindo-se uma hegemonia em relação ao capital religioso e uma hierarquização social em torno de quem os detém, e com isso se tende a repelir os "novos", vistos como profanos, em oposição ao referido corpo sacerdotal, ou ainda hereges, blasfemos ou feiticeiros, quando disputam com esse corpo sacerdotal a administração desses bens de salvação em grupos restritos ou num corpo social mais amplo. C.f. BOURDIEU, Pierre. Gênese e estrutura do campo religioso. In: _ A Economia das trocas simbólicas. Tradução: Sérgio Miceli et al. São Paulo: Editora Perspectiva, 1974. pp. 27-78.
} 
Um exemplo importante disso se encontra no título XI sobre feitiçaria em que o direcionamento no sentido da secularização desse quadro políticoreligioso regalista se coloca claramente. Já no caput que se refere a feiticeiros, sortílegos, adivinhadores, astrólogos judiciários e maléficos, se recorre a grandes teólogos da Igreja para se construir uma argumentação que sustenta que tal forma de pacto é impossível segundo a "sã Teologia", concluindo-se que:

Porquanto o argumento Teológico de que pode haver alguns casos, nos quais os referidos Espíritos diabólicos que nada podem por si mesmos, pos[s]am atormentar as criaturas humanas se Deus lhes permitir, não tem aplicação ao foro dessa legislação. (SIQUEIRA, 1996, p. 949).

E completa:

[...] porque quem tal cresse incorreria em absurdos tais como seriam, um o de querer dar ao demônio os atributos que só pertencem ao Deus de Jacob; outro o de confundir os milagres da Onipotência Divina com as operações do Inferno; outro o de supor, com ofensa da Divina bondade, que esta poderia permitir a uma vil feiticeira, ou infame Astrólogo, que com figuras de tintas ou de carvão; com cozimentos de ervas; com blasfêmias, e outras semelhantes superstições; pudessem privar as gentes da fazenda, da saúde, e até da mesma vida: (...) Porquanto a tudo o referido acresce ter-se claramente visto, que de nenhum dos dois pactos a que se atribuem aqueles poderes houve até o dia de hoje prova alguma" (Ibidem, Loc. Cit.).

O Regimento, em seguida, faz uma menção crítica direta aos manuais de demonologia, utilizados pelas Inquisições desde suas origens medievais e que permaneceram importantes aos inquisidores da Idade Moderna, cuja finalidade era identificar e tipificar pactos com o demônio e os delitos de feitiçaria e bruxaria. O mesmo é feito em relação aos seus autores. Como exemplo desses manuais temos o famoso Malleus Maleficarum. Ele é mencionado no Regimento de 1774, juntamente com seus autores Heinrich Kramer e James Sprenger, neste mesmo título sobre feitiçaria. Na passagem o Regimento diz que

[...] para outros fins humanos e carnais, procuraram [o clero e tiranos do passado anterior às Luzes] disseminar as especulações maravilhosas, e os 
fatos preter naturais [sic], com que abusando da inocência dos povos, e fomentando neles a ignorância, ascenderam no público aquele ardente fanatismo que faz perder aos homens o uso da razão, como o praticaram (por exemplo) na Alta Alemanha Fr. Henrique Institutor, e Fr. Diogo Sprenger, pela publicação intitulada - Maleus Maleficarum [...]. (Ibidem, p. 950)

Os pactos com o demônio são suprimidos como categoria válida para a tipificação de qualquer crime sob justificativa de que não eram plausíveis à luz de uma "sã teologia" e, mais que isso, serviam somente a interesses mundanos e tirânicos, que corrompiam as verdadeiras funções da Inquisição. Além disso, a própria crença na existência de pactos com o demônio e disseminação da mesma nada mais fazia que abusar da ignorância e credulidade dos povos, disseminando fanatismos que não eram mais convenientes à época das Luzes.

Assim, nos capítulos subsequentes do mesmo título, que tratam dos processos e penas aplicáveis a tal tipo de delito, indica-se que a feitiçaria deveria ser tratada de três maneiras: a primeira, como produto de ignorância, sendo necessário "curá-la" por meio da instrução, formal e espiritual; a segunda, no caso de obstinação e pertinácia no delito, dever-seia observar se o réu acredita ou não na existência da feitiçaria, e em caso afirmativo, e insistindo na crença, ele deveria ser tratado como louco e levado ao Hospital Real de Todos os Santos; em último caso, em que o réu comprovadamente utiliza da feitiçaria de forma a conseguir ludibriar incautos para benefício próprio, i. e. similar ao que chamaríamos de charlatanismo hoje, poderia se aplicar punições como o degredo, cárcere ou mesmo a pena capital, conforme o grau de danos que causassem a outras pessoas ou à sociedade (Ibidem, 1996, p. 951-954).

É possível entender o fim do segredo processual, objeto de críticas severas contra o Santo Ofício desde o século XVI, (MARCOCCI; PAIVA, 2013, pp. 79-80) e duramente condenado por uma gama bastante variada de pensadores de toda a Idade Moderna, sejam católicos, protestantes ou cristãos-novos (BETHENCOURT, 2000, p. 335-376), remetendo ao tópico de 
que tal procedimento transformava a Inquisição numa fábrica de culpados por limitar os mecanismos de defesa do réu. ${ }^{10}$ Foi um aspecto, por exemplo, central no libelo anti-inquisitorial atribuído ao padre Antônio Vieira, Notícias recônditas do modo de proceder de Portugal com seus presos. ${ }^{11}$

No título referente às provas que hão de se reputar para a convicção dos réus negativos ou diminutos, confirma-se uma postura contrária ao segredo processual, atribuindo a esse procedimento todo um histórico de penas excessivamente duras e violentas por parte do Santo Ofício, na vigência dos regimentos anteriores. Isso porque:

(...) publicada contra os Réus a prova da Justiça, suprimidos os nomes das testemunhas que os acusaram, expostos pôr este modo os Réus à defesa improvável de uma negativa vaga e genérica, ou à consternações de deporem às cegas, que se declararam com todas quantas pessoas lhe fornece a sua memória, para verem se este pôr modo dão, ou tacam nas pessoas que os acusaram (SIQUEIRA, 1996, p. 914).

E completa, afirmando que:

(...) sem se ter feito a devida reflexão, que não podem acreditar-se declarações vagas, e feitas pela consternação em que o mesmo S. Ofício

\footnotetext{
$10 \mathrm{O}$ segredo que envolvia o processo inquisitorial e a forma com a qual ele absorvia os acusados levaram Antônio José Saraiva a compará-lo ao universo narrado por Franz Kafka no romance $O$ processo (1925). A aproximação foi em grande medida baseada na forma como o protagonista Joseph K., da referida obra, é envolvido em um processo em que não sabe das culpas pelas quais foi acusado, não tendo contato algum com seus acusadores ou juízes ao longo de todo o procedimento, sendo absolutamente absorvido em uma grande burocracia. Assim, Saraiva afirmou que se "há um universo kafkiano com realidade histórica, esse é o universo inquisitorial português", em especial nos processos contra cristãos-novos. O autor argumenta que "tudo ali se encontra: a interminável e enigmática burocracia sem sentido algum para o que penetrava nos seus corredores; a minúcia, o rigor do formulário e das regras processuais através das quais se manifesta um arbítrio total e sem regras; a ignorância da culpa por parte do inculpado, e o sentimento de culpabilidade que o vai pouco a pouco possuindo à medida que se desenvolve a engrenagem; o encontrar-se o réu perante um vácuo insonoro e ao mesmo tempo eloquentemente ameaçador, que não lhe responde a interrogação alguma mas levanta sempre novas perplexidades; a sua lenta degradação até uma abjeção de mendigo suplicante; a ignóbil execução a que finalmente o resigna". SARAIVA, Antônio José. Inquisição e cristãos-novos. Op. Cit. p. 57 e pp. $85-100$

11 "Evidente he, que o sahirem tantos confessos não é realidade da culpa; mas culpa do processo. Isso he tão certo, que com os Christãos novos, se havião de ver nelles as mesmas Confissões, e se se inquiria na mesma fórma da Lei de Mafoma, e das heresias de Calvino, e de Luthero, se havião de ver as mesmas Confissões destas seitas em Portugal, e em toda a parte do Mundo, e isto assim em Christãos velhos, como novos, e em todas as gentes, porque a forma, estilo e o seu rigor, e confusão, são causa de todas as falsidades, e que estão produzindo culpas em tudo sem as haver. "VIEIRA, Antônio, padre. Notícias recônditas do modo de proceder de Portugal com os seus prezos. Lisboa: Imprensa Nacional, 1821. Disponível em <<http://purl.pt/6474 $>$. Acesso em maio/2017.
} 
tinha posto os Réus, com a negação dos nomes das pessoas que os acusaram, e que assim, consternados, o medo da morte lhes fazia fingir declarações que nunca houve (Ibidem, 1996, Loc. Cit.).

Juntamente com a proibição de se conferir algum crédito às testemunhas únicas, exceto nos crimes de solicitação praticado por padres em confessionário (Ibidem, Título IV, Livro II, § 1, 2, 3, 4 e 5. p. 914-915), o regimento reformado da Inquisição de Portugal não somente conferiu aos réus uma maior capacidade de defesa como também, descortinou o "véu de superstição", conforme as palavras do Cardeal da Cunha, que encobriam o processo inquisitorial de um hermetismo que fez parte do que Bartolomé Benassar (BENASSAR, 1979, pp.105-141) chamou de uma "pedagogia do medo", sem a qual o poderio inquisitorial na Idade Moderna dificilmente seria possível.

Estes dois reflexos do processo de secularização nos procedimentos inquisitoriais contribuíram para uma queda progressiva no campo simbólico de uma reverência e temor quanto aos tribunais de fé, o que em grande medida contribuiu, ainda que indiretamente, para ataques cada vez mais veementes à intolerância religiosa institucionalizada no contexto absolutista católico, sobretudo desferidas pelos libertinos luso-brasileiros (CAMILO ROCHA, 2016, pp. 196-240). No entanto cabe salientar que, conforme pesquisas recentes, esse processo secularizador, no que toca à Inquisição, fomentou também a formação de um princípio de estigmatização das formas consideradas "desreguladas" de religião, e. g. religiosidades ligadas a escravos, indígenas, dentre outros (SOUZA, 2013, pp. 313-332).

Em matéria de punições, também se observa no Regimento de 1774 diálogos com os debates das Luzes, por exemplo, no título a respeito da tortura. Na definição sobre o assunto no referido regimento, consta que:

Sendo a tortura uma crudelíssima espécie de averiguação de delitos: Inteiramente estranha dos pios e misericordiosos sentimentos da Igreja Mãe; a mais segura das invenções para castigar um inocente fraco, e para salvar um culpado robusto; ou para extorquir a mentira de ambos: a mais 
exorbitante das regras ordinárias de direito, que não sofrem a imposição de uma pena certa, e tão forte pôr um delito ainda duvidoso (SIQUEIRA, 1996, p. 910).

Há uma semelhança, inclusive textual, com o texto de Cesare Beccaria, Dos delitos e penas, a respeito do mesmo assunto. O pensador italiano escreveu que:

A tortura é muitas vezes um meio seguro de condenar um inocente fraco e de absolver o celerado robusto. É esse, de ordinário, o resultado terrível dessa barbárie que se julga capaz de produzir a verdade, desse uso digno dos canibais, e que os romanos, mau grado a dureza de seus costumes, reservavam exclusivamente aos escravos, vítimas infelizes de um povo cuja feroz virtude tanto se tem gabado (BECCARIA, s/d, p. 65).

A seu modo, sob as limitações de um projeto político-religioso regalista do reformismo pombalino, seu dirigismo cultural e também em conjunto com a própria presunção de que mecanismos como a Inquisição serviriam para civilizar um povo atrasado, as reformas nos estilos dos tribunais inquisitoriais portugueses foram feitas no bojo de discussões a respeito de tipologias de penas e delitos que marcaram o Iluminismo, pautado, sobretudo, no princípio de individualização do corpo, que remete ao Renascimento e que fez parte do processo histórico que, de acordo com Lynn Hunt, deu origem ao que chamamos de "direitos humanos", na contemporaneidade (HUNT, 2009, pp. 70-112).

A individualização da aplicação da pena, referindo-se aqui à limitação dos autos-de-fé públicos a dogmatistas e heresiarcas, e. g. o padre Malagrida, e a ordenação de sua proibição completa para a maioria dos outros crimes, pode ser entendida também nesse conjunto. $\mathrm{O}$ auto-de-fé público, segundo o regimento, não era mais que uma "prova da malignidade jesuítica", segundo o Regimento, que usou essa prática como "fomentadora de ignorância, fanatismo e escândalo às nações estrangeiras" (SIQUEIRA, 1996, p. 930). O mesmo era dito em relação às leituras das listas de penitenciados e sua divulgação em espaços públicos, como nas igrejas, que deveria seria feita tão 
somente sob ordem direta do monarca. Algo que efetivamente jamais aconteceu até o fim da Inquisição portuguesa, em 1821 (SIQUEIRA, 1996, p. 932).

Considerando o que até aqui foi exposto é possível entender que o Regimento da Inquisição de Portugal de 1774 integra um conjunto de ações empreendidas pela Coroa que se articularam com aspectos importantes da vertente católica do Iluminismo e também como parte fundamental de um dirigismo cultural marcante no contexto reformista. Marca uma percepção específica, identificável na cultura letrada portuguesa e luso-brasileira do século XVIII, de que havia um atraso a ser superado em relação às nações além-pirenaicas e que isso seria feito justamente por esta elite. Ela deveria ocupar instituições como a Inquisição e os órgãos de censura e, no limite, figurar no entorno do próprio monarca na qualidade de conselheiros "ilustrados", em substituição aos "aduladores"- identificados com alguns setores tradicionais da nobreza e do clero, marcadamente os jesuítas. Tratase de um processo que integra o desenvolvimento da secularização nos contextos português e luso-brasileiro, dentro do qual existe um quadro de ressignificação e de fortes disputas pelo religioso nos contexto português e luso-brasileiro das Luzes.

\section{Fontes}

BECCARIA, Cesare. Dos delitos e das penas [1764]. S/l. Ed. Eletrônica: Ridendo Castigat Mores. s/d, s/c: Fonte digital: www.jahr.org.

MELO, Sebastião José de Carvalho e [1699-1782]. Cartas e outras obras selectas do Marquez de Pombal, Ministro e Secretario D' Estado D'El Rei D, Joze I com epítome da vida deste Ministro e ornado do seu retrato. Tomo II. Lisboa: Na Typ. De Desiderio Marques Leão, 1822 (Digitalizado por Harvard University, 2009).

SANCHES, Antônio Nunes Ribeiro. Origem da denominação e christão-velho e christão novo em Portugal [1748]. Transcrição e prefácio de Raul Rêgo (1913-2002). Lisboa: Ed. Sá da Costa, Coleção Clássicos, 2010. 
SIQUEIRA, Sônia Aparecida. A disciplina da vida colonial: os regimentos da Inquisição. Revista do Instituto Histórico e Geográfico Brasileiro. Rio de Janeiro: Instituto Histórico e Geográfico Brasileiro, a. 157, nº 392, p. 497-1020, jul. /set. 1996.

VERNEY, Luís Antônio. Cartas Italianas. CURADO, Ana Lúcia; CURADO, Manuel (orgs.). Lisboa: Edições Sílabo, 2008.

VIEIRA, Antônio, padre. Notícias recônditas do modo de proceder de Portugal com os seus prezos. Lisboa: Imprensa Nacional, 1821. Disponível em $<<$ http://purl.pt/6474 $>$ Acesso em maio/2017.

\section{Referências Bibliográficas}

ARAÚJO, Ana Cristina. Dirigismo cultural e formação das elites no pombalismo. In: O Marquês de Pombal e a Universidade. $2^{\text {a }}$ edição. Coimbra: Imprensa da Universidade de Coimbra. 2014, p. 16-48.

BENNASSAR, Bartolomé. L'Inquisition Espagnole: XV $\mathrm{XV}^{\mathrm{e}}-\mathrm{XIX}{ }^{\mathrm{e}}$ siècle. Collection Marabout Université.Paris: Hachete, 1979.

BETHENCOURT, Francisco. História das inquisições: Portugal, Espanha e Itália. Séculos XV-XIX. São Paulo: Companhia das Letras, 2000.

BOURDIEU, Pierre. Gênese e estrutura do campo religioso. In: . $A$ Economia das trocas simbólicas. Tradução: Sérgio Miceli et al. São Paulo: Editora Perspectiva, 1974. p. 27-78.

CAMILO ROCHA, Igor Tadeu. Não se fazem mais excomunhões que prestem nos dias de hoje: libertinos, Reformismo Ilustrado e a defesa da tolerância religiosa no mundo luso-brasileiro (1750-1803). Almanack, Guarulhos, n. 14, p. 196-240, dez. 2016. DOI: <http://dx.doi.org/10.1590/2236-463320161409.>. Disponível em $<$ http://www.scielo.br/scielo.php?script=sci_arttext\&pid=S223646332016000300196 $\& \operatorname{lng}=$ pt\&nrm=iso $>$. Acesso em 24 novembro de 2017.

Libertinos, Tolerância religiosa e Inquisição sob o Reformismo ilustrado luso-brasileiro: formulações, difusão e representações (17561807). [Dissertação de mestrado]. Belo Horizonte: Faculdade de Filosofia e Ciências Humanas da UFMG-FaFICH, 2015. 
FALCON, Francisco Calazans. A Época Pombalina: Política Econômica e Monarquia Ilustrada. 2a edição. São Paulo, Editora Ática, 1993.

HANSEN, João Adolfo. As Liras de Gonzaga: entre retórica e valor de troca. Via Atlan̂tica, v. 1, p. 40-53, 1997.

HUNT, Lynn. A invenção dos direitos humanos: uma história. Tradução: Rosaura Eichenber. São Paulo. Companhia das Letras, 2009.

ISRAEL, Jonathan I. Iluminismo Radical: a filosofia e a construção da modernidade (1650-1750). Tradução: Claudio Blanc. São Paulo: Editora Masdras, 2009 .

MARCOCCI, Giuseppe; PAIVA, José Pedro. História da Inquisição portuguesa: 1536-1821. 1ª edição. Lisboa: A Esfera dos Livros, editora, 2013.

MAXWELL, Keneth. Marquês de Pombal: paradoxo do Iluminismo. Trad. Antônio de Pádua Danesi. Rio de Janeiro: Paz e Terra, 1996.

MONCADA, Luís Cabral de Oliveira. (Org.). Estudos de História do Direito: século XVIII - Iluminismo Católico: Verney-Muratori. Coimbra: Imprensa da Universidade, 1950, v. 3.

NOVINSKY, Anita Waingort. Estudantes brasileiros "afrancesados" na Universidade de Coimbra. A perseguição de Antônio de Morais e Silva. In: COGGIOLA, Osvaldo (org.). A Revolução Francesa e seu impacto na América Latina. Edusp, São Paulo. 1990. p. 357-371.

RAMOS, Luís Antônio de Oliveira. A Inquisição pombalina. In: Sob o signo das Luzes. Lisboa: Imprensa Nacional-Casa da Moeda (Temas Portugueses), 1988.

SANTOS, Antonio Cesar de Almeida. Luzes em Portugal: do terremoto à inauguração da estátua equestre do Reformador. Topoi (Rio de Janeiro), v. 12, n. 22 , p. 75-95, jun. 2011.

SARAIVA, Antônio José. Inquisição e cristãos novos. Lisboa: Editorial Estampa, 1994. $6^{\text {a }}$ edição.

SCHWARTZ, Stuart. Cada um na sua lei: tolerância religiosa e salvação no mundo atlântico ibérico. São Paulo/Bauru: Companhia das Letras/Edusc, 2009.

SOUZA, Evergton Sales. Catolicismo ilustrado e feitiçaria no mundo português. In: FURTADO, Júnia Ferreira; RESENDE, Maria Leônia Chaves de (orgs.). Travessias inquisitoriais das Minas Gerais aos cárceres do Santo Ofício: diálogos e trânsitos 
religiosos no império luso-brasileiro (sécs. XVI-XVIII). Belo Horizonte, Fino Traço$1^{a}$ edição. 2013.Coleção História. p. 313-332.

STEFANO, Roberto Di. Disidencia religiosa y secularización en el siglo XIX iberoamericano: cuestiones conceptuales y metodológicas. Projeto História, São Paulo, $n$ 37, p. 157-178. 2008.

TEIXEIRA, Ivan. Mecenato Pombalino e Poesia Neoclássica: Basílio da Gama e a poética do encômio. São Paulo: Editora da Universidade de São Paulo, 1999.

VILLALTA, Luiz Carlos. Libertinagens e livros libertinos no mundo luso-brasileiro (1740-1802). In: MEGIANI, Ana Paula Torres; ALGRANTI, Leila Mezan (Org.). O império por escrito: formas de transmissão da cultura letrada no mundo ibérico (séculos XVI-XVIII). São Paulo: Alameda/Fapesp/Cátedra Jaime Cortesão, 2009. P. $511-550$

- Usos do livro no mundo luso-brasileiro sob as Luzes: reformas, censura e contestações. Belo Horizonte: Editora Fino Traço, 2015. 